\title{
IPTEKS PENERAPAN METODE PENENTUAN HARGA JUAL NORMAL DALAM PENENTUAN HARGA JUAL JASA (STUDI KASUS PADA USAHA PHOTOCOPY GLORIA MANADO)
}

\author{
Winston Pontoh ${ }^{1}$, Novi Swandari Budiarso ${ }^{2}$ \\ ${ }^{1,2}$ Jurusan Akuntansi, Fakultas Ekonomi dan Bisnis, Universitas Sam Ratulangi, Jl. Kampus Bahu, Manado, \\ 95115, Indonesia \\ E-mail : winstonpontoh@unsrat.ac.id
}

\begin{abstract}
The role of information technology and competition for the recent era is main trigger for rapid growth of business. In order to win the competition, most of business unit especially for the small medium enterprise their selling price (product or service) as it is the main key to estimate the target profit. The business of photocopy is the simple business with rapid turn over but require high investments. This business have growing fast in Manado City, North Sulawesi. The main problem of this business for Manado City is lower skill of managerial for each owners. Based on method to estimate selling price on photocopy business then return on investment provide better information to establish the service selling price.
\end{abstract}

Keywords : return on investment, gross profit margin, selling price

\section{PENDAHULUAN}

Perkembangan bisnis yang semakin kompleks merupakan sebuah perkembangan yang tidak lepas dari peranan teknologi informasi yang sangat dibutuhkan bagi pihak manajemen untuk pengambilan keputusan. Selain itu, persaingan adalah salah satu faktor utama lainnya dalam memicu lajunya perkembangan bisnis saat ini, dimana pasar merupakan target utama bagi setiap entitas bisnis untuk dimenangkan atau dikuasai. Untuk memenangkan persaingan, berbagai strategi diluncurkan oleh setiap entitas bisnis dengan tujuan untuk menguasai target pasar. Kunci kemenangan entitas bisnis dalam melakukan strategi bisnis adalah keunggulan bersaing (David, 2011).

Harga jual produk atau jasa merupakan salah satu kunci untuk mencapai profit yang diinginkan oleh entitas bisnis, sekaligus menjadi kunci penentu apakah entitas bisnis dapat menguasai target pasar atau tidak. Hal ini disebabkan karena adanya harga jual produk atau jasa yang terlalu tinggi akan menyebabkan konsumen menjauhi produk atau jasa yang ditawarkan oleh entitas bisnis. Untuk mengendalikan harga jual, perlu dilakukan pengendalian secara lebih cermat atas biaya-biaya dan investasi yang terjadi dalam entitas bisnis tersebut.

Usaha jasa photocopy merupakan jasa yang terhitung cukup banyak berkembang di kota-kota besar, tidak terkecuali di Manado. Usaha jenis ini merupakan salah satu usaha yang sederhana tetapi memiliki perputaran bisnis yang cukup cepat, di dalam rutinitas operasionalnya membutuhkan jumlah investasi yang tidak sedikit. Disebabkan kondisi bisnis ini, maka ketepatan manajerial sangat dibutuhkan guna menjalankan roda bisnis, karena pada umumnya penanganan manajerial untuk usaha ini masih tergolong tradisional, khususnya dalam hal penetapan harga jual jasa yang masih berbasis pada keadaan pasar, dalam arti harga jual jasa akan disesuaikan dengan kondisi pasar yang ada. Usaha photocopy Gloria merupakan salah satu entitas bisnis yang dapat dikatakan masih memiliki kondisi manajerial yang pada umumnya terjadi pada usaha photocopy lainnya, khususnya pada penetapan harga jual jasa. 
Berdasarkan latar belakang ini, maka penulis merasa sangat penting untuk melakukan kajian terkait dengan masalah metode harga jual normal guna penentuan harga jual jasa, untuk memberikan kontribusi kepada masyarakat melalui karya pengabdian pada masyarakat. Berdasar latar belakang maka permasalahan dalam kajian ini adalah bagaimana penerapan metode harga jual normal dalam penentuan harga jual jasa pada usaha photocopy Gloria di Manado.

\section{TINJAUAN PUSTAKA}

\subsection{Perilaku Biaya}

Warren, dkk (2009), Horngren, dkk (2012), Pontoh (2013), berpendapat bahwa, dalam pencatatan akuntansi (dalam hal ini dapat disebut sebagai akuntansi biaya) untuk biaya-biaya produk dalam perusahaan manufaktur pada dasarnya akan mencatat bagaimana perolehan dan penggunaan atas sumber daya bahan baku, tenaga kerja langsung dan overhead pabrik sebagai biaya produk yang akan dibebankan pada produk sebagai harga pokok produk. Dengan menggunakan sistem dari akuntansi biaya, maka laporan akuntansi akan memberikan informasi biaya yang ada dapat dianalisis lebih lanjut oleh akuntan dan pihak manajemen.

Dengan adanya analisis biaya, maka pihak manajemen akan mendapatkan informasi lebih lanjut mengenai bagaimana biaya-biaya ini akan berperilaku, sehingga dengan adanya identifikasi atas perilaku biaya maka manajemen dapat memperoleh dasar pengambilan keputusan untuk penentuan kegiatan selanjutnya yang akan dituangkan di dalam anggaran perusahaan serta melakukan penilaian atas kinerja kegiatan yang telah dilakukan. Perilaku biaya dapat menentukan metode pembebanan biaya pada sebuah produk yang akan mempengaruhi penentuan harga jual dari produk tersebut. Harga jual produk tersebut dapat menjadi salah satu faktor yang akan menentukan bagaimana sebuah organisasi akan bertindak dalam rangka penguasaan pangsa pasar. Perilaku atas biaya dapat dibagi menjadi 2 (dua) jenis, yaitu :

1. Biaya Variabel (Variable Cost), adalah biaya yang mengalami perubahan secara keseluruhan dalam proporsi tertentu karena adanya perubahan secara keseluruhan dalam proporsi tertentu atas sebuah aktivitas (kegiatan) atau jumlah unit produk. Aktivitas atau jumlah unit produk yang mempengaruhi perubahan atas biaya ini disebut sebagai pemicu biaya (cost driver).

2. Biaya Tetap (Fixed Cost), adalah biaya yang tidak mengalami perubahan secara keseluruhan dalam sebuah periode waktu tertentu karena adanya perubahan secara keseluruhan dalam proporsi tertentu sebuah aktivitas (kegiatan) atau jumlah unit produk.

Dapat disimpulkan bahwa perbedaan utama antara kedua jenis biaya ini adalah biaya variabel akan terkait erat dengan aktivitas (kegiatan) sedangkan biaya tetap akan terkait dengan periode waktu.

\subsection{Teknik Pemisahan Biaya}

Barfield, dkk (2001), Horngren, dkk (2012), Pontoh (2013), mengemukakan bahwa, pemisahan atas biaya menjadi biaya tetap dan biaya variabel, dapat menggunakan beberapa metode berikut ini :

1. Metode Tertinggi-Terendah (High-Low Method).

Metode ini didasarkan pada metode geometri yang memerlukan 2 (dua) titik untuk menentukan arah garis lurus yang akan memiliki titik konstan (intercept/constant) dan titik kemiringan (slope). Metode ini memiliki rumus sebagai berikut :

$$
\text { Biaya Variabel }=\frac{\text { Biaya Tertinggi }- \text { Biaya Terendah }}{\text { Aktivitas Tertinggi }- \text { Aktivitas Terendah }}
$$

Biaya Tetap $=$ Total Biaya Tertinggi - Biaya Variabel 
2. Metode Regresi (Regression Method).

Jika dalam metode tertinggi terendah digunakan 2 (dua) titik utama untuk menentukan titik biaya variabel dan biaya tetap, maka dalam metode regresi, semua data yang terkait dengan total biaya dan aktivitas akan digunakan untuk menentukan biaya variabel dan biaya tetap. Persamaan yang digunakan dalam metode ini adalah sama seperti umumnya penggunaan rumus regresi, yaitu :

$$
\begin{array}{ll}
\text { Total Biaya } & =\text { Biaya Tetap }+ \text { Biaya Variabel } \\
\mathrm{Y} & =\alpha+\beta . \mathrm{X}
\end{array}
$$

\section{3. $\quad$ Metode Pembebanan Biaya}

Kinney \& Raiborn (2011), Hansen, dkk (2009), Van Derbeck (2010), menyebutkan bahwa, beberapa metode pembebanan biaya yang dikenal adalah metode pembebanan biaya penuh (full costing method) yang membebankan biaya pada produk berdasarkan biaya secara penuh atau biaya campuran (mixed method) dan metode pembebanan biaya variabel (variable costing method) yang membebankan biaya pada produk berdasarkan perilaku biaya variabel dan biaya tetap.

\subsection{Penentuan Harga Jual}

\subsubsection{Keputusan Penentuan Harga Jual}

Mulyadi (2002), menyatakan bahwa, umumnya harga jual produk dan jasa standar ditentukan oleh perimbangan permintaan dan penawaran dipasar, sehingga biaya bukan merupakan penentu harga jual. Karena permintaan customer atas produk dan jasa tidak mudah ditentukan oleh manajer penentu harga jual, maka dalam penentuan harga jual, mamajer tersebut akan menghadapi banyak keidakpastian. Selera customer, jumlah pesaing yang memasuki pasar, dan harga jual yang ditentukan oleh pesaing, merupakn contoh faktorfaktor yang sulit untuk diramalkan, yang mempengaruhi pembentukan harga jual produk atau jasa dipasar. Satu-satunya faktor yang memiliki kepastian relative tinggi yang berpengaruh dalam penentuan harga jual adalah biaya.

Biaya memberikan informasi batas bawah suatu harga jual harus ditentukan. Di bawah biaya penuh produk atau jasa, harga jual akan mengakibatkan kerugian bagi perusahaan. Kerugian yang timbul akibat harga jual di bawah biaya produk atau jasa, dalam jamgka waktu tertentu mengakibatkan perusahaan akan berhenti sebagai going concern atau akan mengganggu pertumbuhan perusahaan. dengan demikian manajer penentu harga jual senantiasa memerlukan informasi harga produk atau jasa dalam pengambilan keputusan penentuan harga jual, meskipun biaya tidak menentukan harga jual dan bukan satu-satunya faktor yang harus dipertimbangkan dalam penentuan harga jual.

\subsubsection{Manfaat Informasi Biaya Penuh Dalam Keputusan Penentuan Harga Jual}

Menurut Mulyadi (2002), pada dasarnya, dalam keadaan normal, harga jual produk atau jasa harus dapat menutup biaya penuh yang bersangkutan dengan produk atau jasa dan menghasilkan laba yang dikehendaki. Biaya penuh merupakan total pengorbanan sumber daya untuk menghasilkan produk atau jasa, sehingga semua pengorbanan ini harus dapat ditutup oleh pendapatan yang diperoleh dari penjualan produk atau jasa. Di samping itu, harga jual harus pula dapat menghasilkan laba yang memadai, sepadan dengan investasi yang ditanamkan untuk menghasilkan produk atau jasa. Informasi biaya penuh memberikan manfaat berikut ini bagi manajer penentu harga jual dalam pengambilan keputusan penentuan harga jual :

a. Biaya penuh merupakan titk awal untuk mengurangi ketidakpastian yang dihadapi oleh pengambil keputusan.

b. Biaya penuh merupakan dasar yang memberikan perlindungan bagi perusahaan dari kemungkinan kerugian. 
c. Biaya penuh memberikan informasi yang memungkinkan manajer penentu harga jual melongok struktur biaya perusahaan pesaing.

d. Biaya penuh merupakn dasar untuk pengambilan keputusan perusahaan memasuki pasar.

\subsubsection{Metode Penentuan Harga Jual}

Menurut Mulyadi (2002), dalam keadaan normal, harga jual harus mampu menutup biaya penuh dan menghasilkan laba yang sepadan dengan investasi. Dalam keadaan khusus, harga jual produk tidak dibebani tugas untuk menutup seluruh biaya penuh; setiap harga jual di atas biaya variabel telah memberikan kontribusi dalam menutup biaya tetap. Menurut Mulyadi (2002), Bhimani, dkk (2008), Weetman (2010), terdapat tiga metode penentuan harga jual : penentuan harga jual dalam keadaan normal, penentuan harga jual dalam costtype contract, dan penentuan harga jual pesanan khusus, penentuan harga jual produk atau jasa yang dihasilkan oleh perusahaan yang diatur dengan peraturan Pemerintah. Dalam keempat penentuan harga jual tersebut, biaya merupakan titik tolak untuk perumusan kebijakan harga jual. Dalam keadaan normal, manajer penentu harga jual memerlukan informasi biaya penuh masa yang akan datang sebagai dasar penentuan harga jual produk atau jasa. Metode penentuan harga jual normal seringkali disebut dengan istilah cost-plus pricing, karena harga jual ditentukan dengan menambah biaya masa yang akan datang dengan suatu presentase markup (tambahan di atas jumlah biaya) yang dihitung dengan formula tertentu. Harga jual produk atau jasa dalam keadaan normal ditentukan dengan formula sebagai berikut:

\section{Harga jual $=$ Taksiran biaya penuh + Laba yang diharapkan}

\section{METODE DAN TEKNIK PENERAPAN IPTEKS}

\subsection{Metode Penerapan Ipteks}

Penerapan ipteks ditempuh dengan cara menguraikan dan melakukan pembahasan secara ilmiah dengan pendekatan metode studi kasus yang langsung diaplikasikan pada teknis penghitungan dan analisis atas pemisahan biaya dan penentuan harga jual.

\subsection{Teknik Penerapan Ipteks}

Teknik yang digunakan dalam penerapan ipteks atas pemisahan biaya dan penentuan harga jual adalah sebagai berikut :

1. Melakukan pemisahan biaya dengan menggunakan metode regresi, sehingga diperoleh biaya tetap dan biaya variabel.

2. Menggunakan metode penentuan harga jual normal (normal pricing) untuk menentukan harga jual jasa.

\section{PEMBAHASAN}

\subsection{Gambaran Objek Penerapan Ipteks}

Usaha photocopy Gloria adalah usaha jasa yang didirikan sejak tahun 1994 yang dimiliki oleh Buang Wenas, dan sejak tahun 2008 dialihkan kepada Fredrik Towoliu. Usaha ini berlokasi di Fakultas Ekonomi dan Bisnis (dulu disebut Fakultas Ekonomi) Universitas Sam Ratulangi, Jalan Kampus Bahu Manado. Pada saat ini, Usaha Photocopy Gloria mengoperasikan 3 (tiga) mesin photocopy dengan jumlah karyawan sebanyak 3 (tiga) orang.

\subsection{Pembahasan}

Biaya listrik tidak dapat diklasifikasikan persentase pembebanannya ke dalam jasa dan untuk biaya operasional disebabkan karena alasan dokumentasi. Biaya listrik rata-rata dalam 1 (satu) bulan adalah Rp. 600.000 sampai dengan Rp. 700.000, dalam hal ini diasumsikan untuk dibebankan Rp. 700.000 per bulan. Hal yang sama terjadi pada pembebanan Biaya Sewa Gedung, sehingga dalam kasus ini, biaya listrik dan biaya sewa gedung akan dibebankan seluruhnya ke harga jual jasa. Sebagai tambahan informasi, bahwa usaha tersebut belum terdapat pajak penghasilan yang disetorkan. Data-data guna penentuan 
harga jual dengan menggunakan metode harga jual normal (normal pricing) berdasarkan pendekatan variable costing adalah :

1. Investasi Mesin

Usaha Gloria memiliki mesin photocopy sebanyak 3 (tiga) mesin, dengan perincian sebagai berikut :

\begin{tabular}{lcr}
\hline \multicolumn{1}{c}{ Jenis Mesin } & Jumlah Investasi (Rp.) & Persentase (\%) \\
\hline Mesin I & 36.000 .000 & $39 \%$ \\
Mesin II & 36.000 .000 & $39 \%$ \\
Mesin III & 20.000 .000 & $22 \%$ \\
\hline Total & $\mathbf{9 2 . 0 0 0 . 0 0 0}$ & $\mathbf{1 0 0 \%}$ \\
\hline
\end{tabular}

Catatan : Mesin I dan Mesin II adalah sejenis

\section{Biaya Kertas}

Penghitungan Harga Pokok Kertas/lembar :

\begin{tabular}{lll}
\hline 1 dos @ Rp. 162.000 & $=$ & 5 rim \\
1 rim & $=$ & Rp. $162.000: 5$ rim \\
& $=$ & Rp. 32.400 \\
1 rim & $=500$ lembar kertas \\
Harga pokok per lembar kertas & $=$ Rp. $32.400: 500$ lembar \\
& $=$ Rp. 64,80
\end{tabular}

\section{Biaya Listrik}

Biaya listrik per bulan mengambil jumlah rata-rata pembayaran yang dibulatkan yaitu Rp. 700.000. Biaya listrik per bulan dialokasikan ke setiap mesin berdasarkan persentase investasi mesin-mesin yang ada, sebagai berikut :

\begin{tabular}{lrr}
\hline \multicolumn{1}{c}{ Jenis Mesin } & Persentase (\%) & Jumlah (Rp.) \\
\hline Mesin I & $39 \%$ & 273.913 \\
Mesin II & $39 \%$ & 273.913 \\
Mesin III & $22 \%$ & 152.174 \\
\hline Total & $\mathbf{1 0 0 \%}$ & $\mathbf{7 0 0 . 0 0 0}$ \\
\hline
\end{tabular}

Dengan menggunakan metode regresi dalam fungsi Microsoft Excel (fungsi INTERCEPT dan SLOPE), maka pemisahan biaya tetap dan biaya variabel per mesin menggunakan model sebagai berikut :

\section{Biaya Listrik $=\alpha+\beta$ Biaya Kertas}

Hasil penerapan model menunjukkan bahwa semua mesin menunjukkan koefisien biaya variabel 0 (nol), sehingga seluruh biaya listrik diklasifikasikan sebagai biaya tetap.

\section{Biaya Sewa Gedung}

Berdasarkan kebijakan manajemen, seluruh biaya sewa gedung diklasifikasikan sebagai biaya tetap, dengan alokasi ke setiap mesin didasarkan pada persentase investasi mesin, sebagai berikut :

\begin{tabular}{lrr}
\hline \multicolumn{1}{c}{ Jenis Mesin } & Persentase (\%) & Jumlah (Rp.) \\
\hline Mesin I & $39 \%$ & 371.739 \\
Mesin II & $39 \%$ & 371.739 \\
Mesin III & $22 \%$ & 206.522 \\
\hline Total & $\mathbf{1 0 0 \%}$ & $\mathbf{9 5 0 . 0 0 0}$ \\
\hline
\end{tabular}


Berikut ini akan disajikan data-data rekapitulasi keuangan bulanan setiap mesin guna penentuan Tingkat Pengembalian Investasi (Return on Investment - ROI) yang akan digunakan pada rekayasa markup harga jual jasa dan kemudian akan menjadi penentu harga jual jasa. Sebagai pembanding, persentase laba kotor (Gross Profit Margin - GPM) juga akan digunakan sebagai dasar markup harga jual jasa.

\begin{tabular}{ccccccrcr}
\hline Bulan & Pendapatan & $\begin{array}{c}\text { Biaya } \\
\text { Tinta }\end{array}$ & $\begin{array}{c}\text { Kertas } \\
\text { (lbr) }\end{array}$ & $\begin{array}{c}\text { Biaya } \\
\text { Kertas }\end{array}$ & $\begin{array}{c}\text { Biaya } \\
\text { Gaji }\end{array}$ & $\begin{array}{c}\text { Biaya } \\
\text { Pemeliharaan }\end{array}$ & $\begin{array}{c}\text { Biaya } \\
\text { Listrik }\end{array}$ & $\begin{array}{c}\text { Sewa } \\
\text { Gedung }\end{array}$ \\
\hline Jan & $3,692,500$ & 492,333 & 14,770 & 957,096 & $1,000,000$ & 75,000 & 273,913 & 371,739 \\
Feb & $3,720,000$ & 496,000 & 14,880 & 964,224 & $1,000,000$ & 75,000 & 273,913 & 371,739 \\
Mar & $3,700,000$ & 493,333 & 14,800 & 959,040 & $1,000,000$ & 75,000 & 273,913 & 371,739 \\
Apr & $3,712,500$ & 495,000 & 14,850 & 962,280 & $1,000,000$ & 75,000 & 273,913 & 371,739 \\
Mei & $3,710,000$ & 494,667 & 14,840 & 961,632 & $1,000,000$ & 75,000 & 273,913 & 371,739 \\
Jun & $3,750,000$ & 500,000 & 15,000 & 972,000 & $1,000,000$ & 75,000 & 273,913 & 371,739 \\
Jul & $3,715,000$ & 495,333 & 14,860 & 962,928 & $1,000,000$ & 75,000 & 273,913 & 371,739 \\
Agt & $3,950,000$ & 526,667 & 15,800 & $1,023,840$ & $1,000,000$ & 75,000 & 273,913 & 371,739 \\
Sep & $3,807,500$ & 507,667 & 15,230 & 986,904 & $1,000,000$ & 75,000 & 273,913 & 371,739 \\
Okt & $3,745,000$ & 499,333 & 14,980 & 970,704 & $1,000,000$ & 75,000 & 273,913 & 371,739 \\
Nov & $3,750,000$ & 500,000 & 15,000 & 972,000 & $1,000,000$ & 75,000 & 273,913 & 371,739 \\
Des & $3,747,500$ & 499,667 & 14,990 & 971,352 & $1,000,000$ & 75,000 & 273,913 & 371,739 \\
\hline & $\mathbf{4 5 , 0 0 0 , 0 0 0}$ & $\mathbf{6 , 0 0 0 , 0 0 0}$ & $\mathbf{1 8 0 , 0 0 0}$ & $\mathbf{1 1 , 6 6 4 , 0 0 0}$ & $\mathbf{1 2 , 0 0 0 , 0 0 0}$ & $\mathbf{9 0 0 , 0 0 0}$ & $\mathbf{3 , 2 8 6 , 9 5 7}$ & $\mathbf{4 , 4 6 0 , 8 7 0}$ \\
\hline
\end{tabular}

\begin{tabular}{ccccccrcr}
\hline Bulan & Pendapatan & $\begin{array}{c}\text { Biaya } \\
\text { Tinta }\end{array}$ & $\begin{array}{c}\text { Kertas } \\
\text { (lbr) }\end{array}$ & $\begin{array}{c}\text { Biaya } \\
\text { Kertas }\end{array}$ & $\begin{array}{c}\text { Biaya } \\
\text { Gaji }\end{array}$ & $\begin{array}{c}\text { Biaya } \\
\text { Pemeliharaan }\end{array}$ & $\begin{array}{c}\text { Biaya } \\
\text { Listrik }\end{array}$ & $\begin{array}{c}\text { Sewa } \\
\text { Gedung }\end{array}$ \\
\hline Jan & $3,692,500$ & 492,333 & 14,770 & 957,096 & $1,000,000$ & 75,000 & 273,913 & 371,739 \\
Feb & $3,720,000$ & 496,000 & 14,880 & 964,224 & $1,000,000$ & 75,000 & 273,913 & 371,739 \\
Mar & $3,700,000$ & 493,333 & 14,800 & 959,040 & $1,000,000$ & 75,000 & 273,913 & 371,739 \\
Apr & $3,712,500$ & 495,000 & 14,850 & 962,280 & $1,000,000$ & 75,000 & 273,913 & 371,739 \\
Mei & $3,710,000$ & 494,667 & 14,840 & 961,632 & $1,000,000$ & 75,000 & 273,913 & 371,739 \\
Jun & $3,750,000$ & 500,000 & 15,000 & 972,000 & $1,000,000$ & 75,000 & 273,913 & 371,739 \\
Jul & $3,715,000$ & 495,333 & 14,860 & 962,928 & $1,000,000$ & 75,000 & 273,913 & 371,739 \\
Agt & $3,950,000$ & 526,667 & 15,800 & $1,023,840$ & $1,000,000$ & 75,000 & 273,913 & 371,739 \\
Sep & $3,807,500$ & 507,667 & 15,230 & 986,904 & $1,000,000$ & 75,000 & 273,913 & 371,739 \\
Okt & $3,745,000$ & 499,333 & 14,980 & 970,704 & $1,000,000$ & 75,000 & 273,913 & 371,739 \\
Nov & $3,750,000$ & 500,000 & 15,000 & 972,000 & $1,000,000$ & 75,000 & 273,913 & 371,739 \\
Des & $3,747,500$ & 499,667 & 14,990 & 971,352 & $1,000,000$ & 75,000 & 273,913 & 371,739 \\
\hline & $\mathbf{4 5 , 0 0 0 , 0 0 0}$ & $\mathbf{6 , 0 0 0 , 0 0 0}$ & $\mathbf{1 8 0 , 0 0 0}$ & $\mathbf{1 1 , 6 6 4 , 0 0 0}$ & $\mathbf{1 2 , 0 0 0 , 0 0 0}$ & $\mathbf{9 0 0 , 0 0 0}$ & $\mathbf{3 , 2 8 6 , 9 5 7}$ & $\mathbf{4 , 4 6 0 , 8 7 0}$ \\
\hline
\end{tabular}

\begin{tabular}{ccccccccc}
\hline Bulan & Pendapatan & $\begin{array}{c}\text { Biaya } \\
\text { Tinta }\end{array}$ & $\begin{array}{c}\text { Kertas } \\
\text { (lbr) }\end{array}$ & $\begin{array}{c}\text { Biaya } \\
\text { Kertas }\end{array}$ & $\begin{array}{c}\text { Biaya } \\
\text { Gaji }\end{array}$ & $\begin{array}{c}\text { Biaya } \\
\text { Pemeliharaan }\end{array}$ & $\begin{array}{c}\text { Biaya } \\
\text { Listrik }\end{array}$ & $\begin{array}{c}\text { Sewa } \\
\text { Gedung }\end{array}$ \\
\hline Jan & $3,692,500$ & 492,333 & 14,770 & 957,096 & $1,000,000$ & 75,000 & 152,174 & 206,522 \\
Feb & $3,720,000$ & 496,000 & 14,880 & 964,224 & $1,000,000$ & 75,000 & 152,174 & 206,522 \\
Mar & $3,700,000$ & 493,333 & 14,800 & 959,040 & $1,000,000$ & 75,000 & 152,174 & 206,522 \\
Apr & $3,712,500$ & 495,000 & 14,850 & 962,280 & $1,000,000$ & 75,000 & 152,174 & 206,522 \\
Mei & $3,710,000$ & 494,667 & 14,840 & 961,632 & $1,000,000$ & 75,000 & 152,174 & 206,522 \\
Jun & $3,750,000$ & 500,000 & 15,000 & 972,000 & $1,000,000$ & 75,000 & 152,174 & 206,522 \\
Jul & $3,715,000$ & 495,333 & 14,860 & 962,928 & $1,000,000$ & 75,000 & 152,174 & 206,522 \\
Agt & $3,950,000$ & 526,667 & 15,800 & $1,023,840$ & $1,000,000$ & 75,000 & 152,174 & 206,522 \\
Sep & $3,807,500$ & 507,667 & 15,230 & 986,904 & $1,000,000$ & 75,000 & 152,174 & 206,522 \\
Okt & $3,745,000$ & 499,333 & 14,980 & 970,704 & $1,000,000$ & 75,000 & 152,174 & 206,522 \\
Nov & $3,750,000$ & 500,000 & 15,000 & 972,000 & $1,000,000$ & 75,000 & 152,174 & 206,522 \\
Des & $3,747,500$ & 499,667 & 14,990 & 971,352 & $1,000,000$ & 75,000 & 152,174 & 206,522 \\
\hline & $\mathbf{4 5 , 0 0 0 , 0 0 0}$ & $\mathbf{6 , 0 0 0 , 0 0 0}$ & $\mathbf{1 8 0 , 0 0 0}$ & $\mathbf{1 1 , 6 6 4 , 0 0 0}$ & $\mathbf{1 2 , 0 0 0 , 0 0 0}$ & $\mathbf{9 0 0 , 0 0 0}$ & $\mathbf{1 , 8 2 6 , 0 8 7}$ & $\mathbf{2 , 4 7 8 , 2 6 1}$ \\
\hline
\end{tabular}

Dalam penentuan harga jual jasa, markup atas biaya variabel adalah merupakan salah satu faktor yang paling penting. Akan tetapi, dalam unsur markup, laba yang diharapkan perlu ditetapkan oleh pihak manajemen terlebih dahulu. Dalam Usaha Photocopy Gloria, 
penentuan laba yang diharapkan masih didasarkan pada anggapan tradisional yaitu dasar persentase laba kotor (GPM) yang mengambil dasar tolak ukur harga jual yang berlaku di dalam pasar.

\section{Penentuan Harga Jual - Mesin I}

Adapun perbandingan penentuan laba yang diharapkan untuk Mesin I adalah :

\section{Tingkat Pengembalian Investasi :}

(Rp.)

Pendapatan
Biaya Tinta
Biaya Kertas
Biaya Karyawan
Biaya Pemeliharaan
Biaya Listrik
Biaya Sewa Gedung
Laba Bersih
Investasi Mesin I
ROI

45.000 .000

$-6.000 .000$

$-11.664 .000$

$-12.000 .000$

$-900.000$

$-3.286 .957$

$-4.460 .870$

6.688 .174

36.000 .000

Persentase Laba Kotor :

Harga Jual

Biaya Kertas

Biaya Tinta $-33,33$

Laba Kotor

GPM

0,61 atau $61 \%$

Dengan mengambil dasar laba yang diharapkan dari Tingkat Pengembalian Investasi (ROI) atau Persentase Laba Kotor (GPM), maka penentuan harga jual jasa adalah sebagai berikut :

\section{Penentuan Harga Jual :}

Markup :

Biaya Tetap

Laba yang Diharapkan

Biaya Variabel

Markup

Harga Jual :

Biaya Variabel

Markup

Jumlah Lembar

Harga Jual Jasa

\section{Dasar ROI}

20.647 .826

$6.688 .174 *$

27.336 .000

17.664 .000

1,55 atau $155 \%$

17.664 .000

27.336 .000

45.000 .000

180.000

Rp. 250 per lembar

*19\% x Rp. 36.000.000

\section{Dasar GPM}

20.647 .826

$\frac{21.868 .800^{* *}}{42.516 .626}$

17.664 .000

2,41 atau $241 \%$

17.664 .000

42.516 .626

60.180 .626 180.000

\begin{tabular}{rr}
180.000 & 180.000 \\
\hline Rp. 250 per lembar & Rp. 334 per lembar \\
*19\% x Rp. 36.000.000 & **61\% $\mathbf{\text { Rp. 36.000.000 }}$
\end{tabular}

Sebagai tambahan, apabila pengembalian atas investasi Mesin I mengambil dasar waktu (pay back period), maka lamanya waktu pengembalian investasi adalah :

$$
\begin{array}{clcc}
\text { Jumlah Investasi } & \text { Laba Bersih } & = & \text { Lama Waktu } \\
\text { Rp. 36.000.000 } & \text { Rp. 6.688.174 } & = & 5,38 \text { tahun }
\end{array}
$$




\section{Penentuan Harga Jual - Mesin II}

Adapun perbandingan penentuan laba yang diharapkan untuk Mesin II adalah :

\section{Tingkat Pengembalian Investasi :}

(Rp.)
Pendapatan
Biaya Tinta
Biaya Kertas
Biaya Karyawan
Biaya Pemeliharaan
Biaya Listrik
Biaya Sewa Gedung
Laba Bersih
Investasi Mesin I

45.000 .000

$-6.000 .000$

$-11.664 .000$

$-12.000 .000$

$-900.000$

$-3.286 .957$

$-4.460 .870$

ROI

6.688 .174

36.000 .000

0,19 atau $19 \%$

\section{Persentase Laba Kotor :}

Harga Jual

Biaya Kertas

Biaya Tinta

Laba Kotor

GPM

0,61 atau $61 \%$

Dengan mengambil dasar laba yang diharapkan dari Tingkat Pengembalian Investasi (ROI) atau Persentase Laba Kotor (GPM), maka penentuan harga jual jasa adalah :

\begin{tabular}{lrr}
\hline \multicolumn{1}{c}{ Penentuan Harga Jual : } & & \multicolumn{1}{c}{ Dasar GPM } \\
Markup : & Dasar ROI & 20.647 .826 \\
Biaya Tetap & 20.647 .826 & $21.868 .800 * *$ \\
Laba yang Diharapkan & $6.688 .174 *$ & 42.516 .626 \\
& 27.336 .000 & 17.664 .000 \\
Biaya Variabel & 17.664 .000 & 2,41 atau $241 \%$ \\
Markup & 1,55 atau $155 \%$ & 17.664 .000 \\
Harga Jual : & 17.664 .000 & 42.516 .626 \\
Biaya Variabel & 27.336 .000 & 60.180 .626 \\
Markup & 45.000 .000 & 180.000 \\
\cline { 2 - 3 } & 180.000 & Rp. 334 per lembar \\
Jumlah Lembar & Rp. 250 per lembar & **61\% $\mathbf{R p . ~ 3 6 . 0 0 0 . 0 0 0}$ \\
Harga Jual Jasa & $* \mathbf{1 9 \%} \mathbf{x}$ Rp. 36.000.000
\end{tabular}

Sebagai tambahan, apabila pengembalian atas investasi Mesin II mengambil dasar waktu (pay back period), maka lamanya waktu pengembalian investasi adalah :

\section{Jumlah Investasi : Laba Bersih = Lama Waktu Rp. 36.000.000 : Rp. 6.688.174 = 5,38 tahun}

\section{Penentuan Harga Jual - Mesin III}

Adapun perbandingan penentuan laba yang diharapkan untuk Mesin III adalah : 
Tingkat Pengembalian Investasi :

Pendapatan

(Rp.)

Biaya Tinta

45.000 .000

$-6.000 .000$

Biaya Kertas

$-11.664 .000$

Biaya Karyawan

$-12.000 .000$

Biaya Pemeliharaan

$-900.000$

Biaya Listrik

$-1.826 .087$

Biaya Sewa Gedung

$-2.478 .261$

Laba Bersih

Investasi Mesin I

10.131 .652

ROI 20.000 .000

0,51 atau 51\%

\section{Persentase Laba Kotor :}

Harga Jual

Biaya Kertas

Biaya Tinta

Laba Kotor

GPM

0,61 atau $61 \%$

Penentuan harga jual jasa berdasar ROI atau GPM adalah sebagai berikut :

\section{Penentuan Harga Jual :}

Markup :

Biaya Tetap

Laba yang Diharapkan

Biaya Variabel

Markup

Harga Jual :

Biaya Variabel

Markup

Jumlah Lembar

Harga Jual Jasa
Dasar ROI

17.204 .348

Dasar GPM

$10.131 .652 *$

27.336 .000

17.204.348

$12.149 .333 * *$

17.664 .000

17.664 .000

1,55 atau $155 \%$ 1,66 atau $166 \%$

\begin{tabular}{rr}
1,55 atau $155 \%$ & 1,66 atau $166 \%$ \\
\hline
\end{tabular}

17.664 .000

17.664 .000

27.336 .000 29.353.681

45.000 .000

47.017 .681

180.000 180.000

Rp. 250 per lembar Rp. 261 per lembar

*51\% x Rp. 20.000.000 **61\% x Rp. 20.000.000

Lamanya pengembalian investasi dari Mesin III adalah :

$\begin{array}{ccccc}\text { Jumlah Investasi } & : & \text { Laba Bersih } & = & \text { Lama Waktu } \\ \text { Rp. 20.000.000 } & : & \text { Rp. 10.131.652 } & = & 1,97 \text { tahun }\end{array}$

\section{KESIMPULAN DAN SARAN}

\subsection{Kesimpulan}

Dasar menentukan laba yang diharapkan dapat mengambil nilai dari Tingkat Pengembalian Investasi (Return on Investment - ROI) atau Persentase Laba Kotor (Gross Profit Margin - GPM). Terdapat perbedaan yang cukup signifikan atas harga jual dengan menggunakan Mesin I dan Mesin II untuk dasar Tingkat Pengembalian Investasi (Return on Investment - ROI) atau Persentase Laba Kotor (Gross Profit Margin - GPM). Akan tetapi tidak begitu jauh berbeda untuk diterapkan pada harga jual dengan menggunakan Mesin III. 
Investasi pada Mesin III adalah investasi yang paling cepat pengembaliannya yaitu 1,97 tahun.

\subsection{Saran}

Bagi pihak manajemen disarankan untuk menggunakan dasar persentase laba kotor dalam menentukan laba yang diharapkan, sehingga harga jual jasa dapat memberikan keuntungan yang optimal, akan tetapi untuk menjaga pangsa pasar, penggunaan dasar ROI masih cukup wajar untuk diterapkan.

\section{DAFTAR PUSTAKA}

Barfield, Jesse T., Raiborn, Cecily A., \& Kinney, Michael R. 2001. Cost Accounting : Traditions and Innovations, $4^{\text {th }}$ Edition. South-Western Educational Publishing.

Bhimani, Alnoor, Horngren, Charles T., Datar, Srikant M., \& Foster, George. 2008. Management and Cost Accounting, $4^{\text {th }}$ Edition. Prentice-Hall, Inc.

David, Fred. R. 2011. Strategic Management, Concepts and Cases, $13^{\text {th }}$ Edition. Pearson Education, Inc.

Hansen, Don R., Mowen, Maryanne M., \& Guan, Liming. 2009. Cost Management : Accounting and Control, $6^{\text {th }}$ Edition. South-Western, Cengage Learning.

Horngren, Charles T., Datar, Srikant M., \& Rajan, Madhav V. 2012. Cost Accounting : A Managerial Emphasis, $14^{\text {th }}$ Edition. Pearson Education Inc.

Horngren, Charles T., Harrison Jr, Walter T., \& Oliver, M. Suzanne. 2012. Accounting, $9^{\text {th }}$ Edition. Pearson Education Inc.

Kinney, Michael R., \& Raiborn, Cecily A. 2011. Cost Accounting: Foundations and Evolutions, $8^{\text {th }}$ Edition. South-Western, Cengage Learning.

Mulyadi, 2002, Akuntansi Manajemen : Konsep, Manfaat dan Rekayasa, Edisi 3, Salemba Empat.

Pontoh, Winston. 2013. Akuntansi : Konsep dan Aplikasi. Halaman Moeka, Jakarta.

Van Derbeck, Edward J. 2010. Principles of Cost Accounting, $15^{\text {th }}$ Edition. South-Western, Cengage Learning.

Warren, Carl. S, James M. Reeve, \& Jonathan E. Duchac. 2009. Accounting, $23^{\text {rd }}$ Edition. South Western Cencage Learning.

Weetman, Pauline. 2010. Management Accounting, $2^{\text {nd }}$ Edition. Pearson Education Limited. 